\title{
The Effectiveness of Development Results of Pro-show Media Based on Solar System Poem and Song on Student Learning Outcomes
}

\author{
Yeni Kurniawanti ${ }^{1^{*}}$, Budiyono Saputro ${ }^{2}$, Sakshi Bahuguna ${ }^{3}$ \\ ${ }^{1}$ Institut Agama Islam Negeri Salatiga, Indonesia \\ ${ }^{2}$ Institut Agama Islam Negeri Salatiga, Indonesia \\ ${ }^{3}$ Manav Rachna University, India \\ *Correspondence to: yenikurniawanti@gmail.com
}

\begin{abstract}
The purpose of this study was to determine the effectiveness of the results of the development of poem and song-based proshow media on MI Al-Falah Soropadan District of Pringsurat students' learning outcomes in the solar system material. The research method used is quantitative with One-Group Pretest-posttest design. The subjects of the study were sixth graders of MI ALFalah Soropadan and teachers in Pringsurat District. The research instruments were pretest and posttest of solar material. T-test results obtained $t-73.676, p=0.00<0.05$, which means that the poem and song-based proshow media development results are effective on MI Al-Falah Soropadan Pringsurat District students' learning outcomes in solar system material. This study concluded poem and song-based proshow media provide solutions for teachers and students in increasing mastery of science subjects.
\end{abstract}

Keywords: media; proshow; poems; songs

Recommended citation: Kurniawanti, Y., Saputro, B. \& Bahuguna, S. (2020). The Effectiveness of Development Results of Pro-show Media Based on Solar System Poem and Song on Student Learning Outcomes. Journal of Innovation in Educational and Cultural Research, 1(1), 1-6

\section{INTRODUCTION}

The material of the solar system is an essential part of science learning to be conveyed with the right media and methods. Following research conducted by Portanata et al. (2017) that the method used by teachers in learning solar system material is the solar system model. Based on observations of 45 teachers and 113 Madrasah Ibtidaiyah students in Pringsurat District, on 12-20 February 2020 through questionnaires and interviews, showed that the method used in learning in schools so far only used lectures and memorization. It causes student motivation and learning outcomes are not optimal. According to Imran (2014); Patrini, et al. (2020) video media can increase motivation, add experience, can be seen in groups, can be played repeatedly, and also instill affective attitudes. The media used also tends to be modest. Based on the explanation above, the researchers conducted the development of learning media based on poem and songs. The core of its development is a learning media in the form of video songs as its products, with poems containing summaries of solar system material that are packaged in a variety of song choices. The product produced from this development can overcome the problems and difficulties in learning solar system material for the sixth graders in MI students in Pringsurat District. It is under the purpose of developing this media, which is to assist teachers in delivering science subject matter in a secure, concise and enjoyable way. The benefits that can be taken from the development of this media are as learning media that can motivate students in the process of teaching and learning activities that are creative, innovative and fun.

As for previous research that is relevant to support research, as conducted by Tantriyadi (2013), states the importance of applying learning applications in the delivery of solar system material. Setiyadi (2016), in his research, stated that the learning of solar system materials could be effective and fun because it is delivered using the Computer Assisted Instruction (CAI) method. Masri and Lasmi (2018) in their research also said that the learning of solar system material would be more effective and efficient if it was presented in the form of 3D audio and visual using the Augmented Reality (AR) method. Kırıkkaya (2009) suggested the results of his research that learning science can be applied using television news broadcast media. The statement is in line with research by Liu and Chen (2013) which shows that learning science will be more effective if delivered with an educational game model because students are more motivated. Susilawati (2014), in her research, stated that learning obtained through the singing method could increase enthusiasm, participant involvement, communication between students, and communication between teachers and students. 
Another relevant study is the study conducted by Sari (2017) showing that the method of singing with visual-based media proved to be effective in improving learning outcomes. Research on songs conducted by Ikhsan (2017) on improving pronunciation through dictation songs or speech texts then written can improve the ability of pronunciation to students and will be more effective if the song selection is given to students, not teachers. Džanić and Pejić (2016) used songs to measure motivation, skills and mastery of English vocabulary through questionnaires and proved to have a positive effect on increasing vocabulary mastery. Indicators of success are indicated by an increase in imagination, creativity, motivation and learning outcomes. Haghverdi (2015), in his research, found that song and film methods can improve students' language skills. Research on the use of song media was also conveyed by Mizener (2008) that learning will be maximized with song media because students develop more quickly and have enough capital to communicate.

Gambarte et al. (2014) suggested that the use of multimedia is essential, can increase security, and reduce the risk of problems in a school. Çı̆grık and Ergül (2010), in their research, also suggested that the use of the internet can be used to achieve knowledge effectively so that students can think logically. Akhondi (2011) suggested that the use of multimedia can improve students' spelling abilities. Lee and Osman (2012) suggested the results that the development of interactive multimedia modules with pedagogical agents (IMMPA) could improve the effectiveness of learning. Gorys et al. (2004) suggested that the use of proshow media can improve learning outcomes in writing persuasion paragraphs. Based on the results of previous studies, the equation with this research is the similarity of the media used, namely songs. The difference lies in the learning device used. Previous research uses the method of listening, visualization, audio, and puppets, while this research uses the development media in the form of song albums.

Learning, as stated by Sardiman (2007), implies that a change in behaviour or appearance in a series of activities, for example, by reading, observing, listening, imitating. Meanwhile, according to Baharuddin (2010), learning is an activity carried out by someone to get a change in themselves through training or experience activities. Sudjana views learning as a process that is marked by a change in a person as a result of the learning process that can be shown in various forms such as changes in knowledge, understanding, attitudes and behaviour, skills, conversations, habits, and changes in aspects that exist in individuals who are learning (Sudjana, 2009).

Gorys (2004) suggested that poem is a vocal style that is used to express thoughts or with word order in songs. Researchers use a poem to present a summary of solar system material. Purnomo and Subagyo (2015) also suggested that the song is in the form of tone or poem to express thoughts and feelings. Kasihani (2010) said that learning with song media in the classroom has the characteristics of containing words with a specific theme, repeated language elements, using song forms and easily memorized by students. Huda (2019) stated that learning using the song method, which is part of the auditory learning style, will be more effective in improving learning outcomes because this learning will accelerate the understanding of sounds that are either created or remembered. According to Walker (2017), the addition of the use of musical instruments also much supports academic success, so it needs to be applied. Researchers also use various types of songs that include a variety of songs dolanan. It is following the results of research by Hartiningsih (2015) that the dolanan song contains three essential elements, namely knowledge, attitude and physical skills, so it is crucial to convey to students.

Proshow is a media that can display slides, images, music or effects easily and can be edited as needed. In line with research conducted by Suprijono (2015), who argues that learning with IT media should be based on individual and social needs according to real or contextual conditions. The results of the researchers' interview with the proshow resource person, Saputro (2020) who were participants in the 2017 Ministry of Religion Community Outreach Training, showed that the proshow is a media or tool that can be used to convey learning information. The media is in the form of pictures, audio, videos or slides with the aim that students are more motivated and easy to understand the material so that learning outcomes increase.

The problem of this research is the students' learning outcomes of the solar system material which still need to be optimized from the initial study found due to students' learning completeness is still low. The purpose of this research is to find out the effectiveness of the development results of pro show media related to poetry and song about learning outcomes of solar system material in MI students. Media used as a treatment of problems found in the initial study of this research.

\section{METHODS}

The type of this research is quantitative research with a One-Group Pretest-posttest design that refers to (Koch et al. 2019). The experimental research design used in this study was carried out in one randomly chosen group. Students of MI Al-Falah Soropadan Pringsurat sub-district are the samples of this study using the purposive sampling technique. The pretest is done before the learning treatment with proshow learning media on the solar system is given. After treatment, measurement through posttest. Thus, it can be known accurately to compare before and after treatment. 


\section{Participants}

The target of the study was madrasah students who were studying material about the solar system. There are 25 students as the participants, with 12 male students and 13 female students. The research objectives have unique characteristics because they come from different regions and families with economic disadvantages. The family's unfortunate economic situation is related to the lack of carrying capacity of learning resources owned by participants. Their learning resources are only limited to textbooks given by the government, so they are not accustomed to learning with interactive learning media. All participants came from Javanese culture.

\section{Instrument}

Questions used to measure values as learning outcomes are developed in the form of multiple choice. The number of answer choices is four in form A, B, C, and D. Before being used, the questions were gone through a content validation by a science learning substance expert who has expertise in physics. Before being used by experts, the validation results of the multiple-choice question instrument, have been declared content valid so that it can be used as an instrument for data collection in this study.

\section{Data Collection}

The primary research data collection uses multiple-choice test questions. Questions are made in the same form but given in two stages, before and after treatment. Pretest and posttest questions have the same form and difficulty level. The questions are limited to the solar system. Data on the effectiveness of instructional media is collected by using media effectiveness instruments obtained from the assessment of media experts and observations during the use of media in learning.

\section{Data Analysis}

Learning outcomes data were analyzed for validity, mean value, median value, standard deviation, minimum value and maximum value at the research target. The data analysis technique used the research design "OneGroup Pretestposttest Design", then the t-test was carried out. Description analysis is carried out from the results of product development in the form of proshow media, which is developed based on poems and songs. The description is done by analyzing the specifications of the media produced. Data normality test is done by the Shapiro test to be analyzed before and after using the media in learning. The effectiveness of the media used was analyzed using paired sample t-test. Reference the results of the test by looking at the value of the table. If the results obtained t-count so that it can be decided the results of the development of proshow media-based of poems and songs about solar system material is effective or not on the value of student learning outcomes.

\section{RESULT AND DISCUSSION}

The development results describe that the form of proshow media based on poems and songs is in the form of a video album containing poems about solar system material is packaged in a variety of song variations and an attractive image display. Proshow media based on poem and songs from the solar system as a result of developments such as Figure 1 and Figure 2.

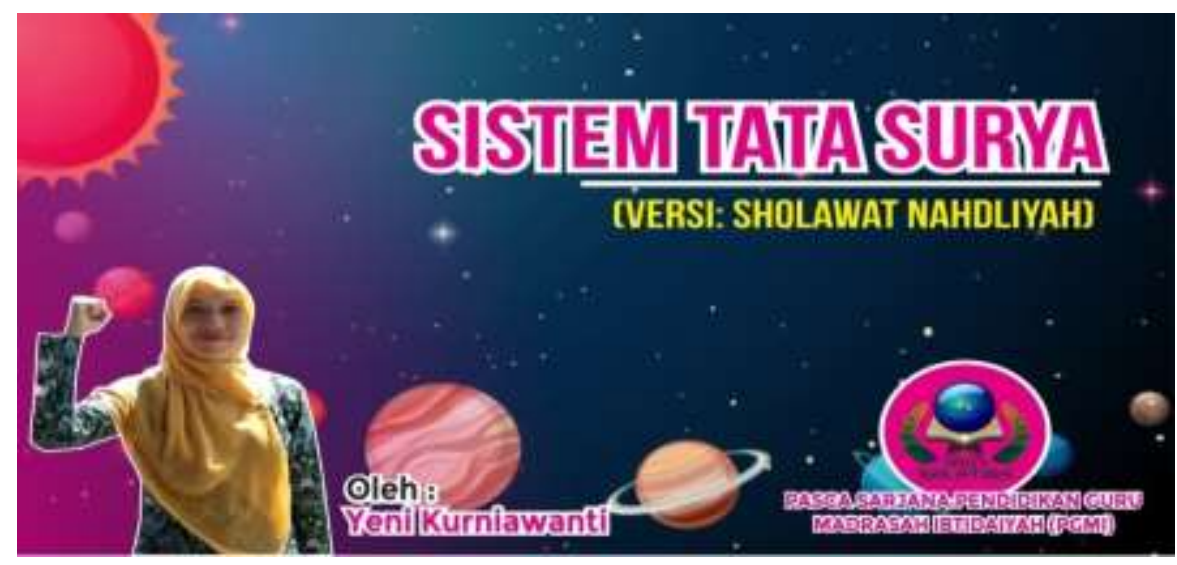

Figure 1. Front Cover

Source: Researcher's documentation 

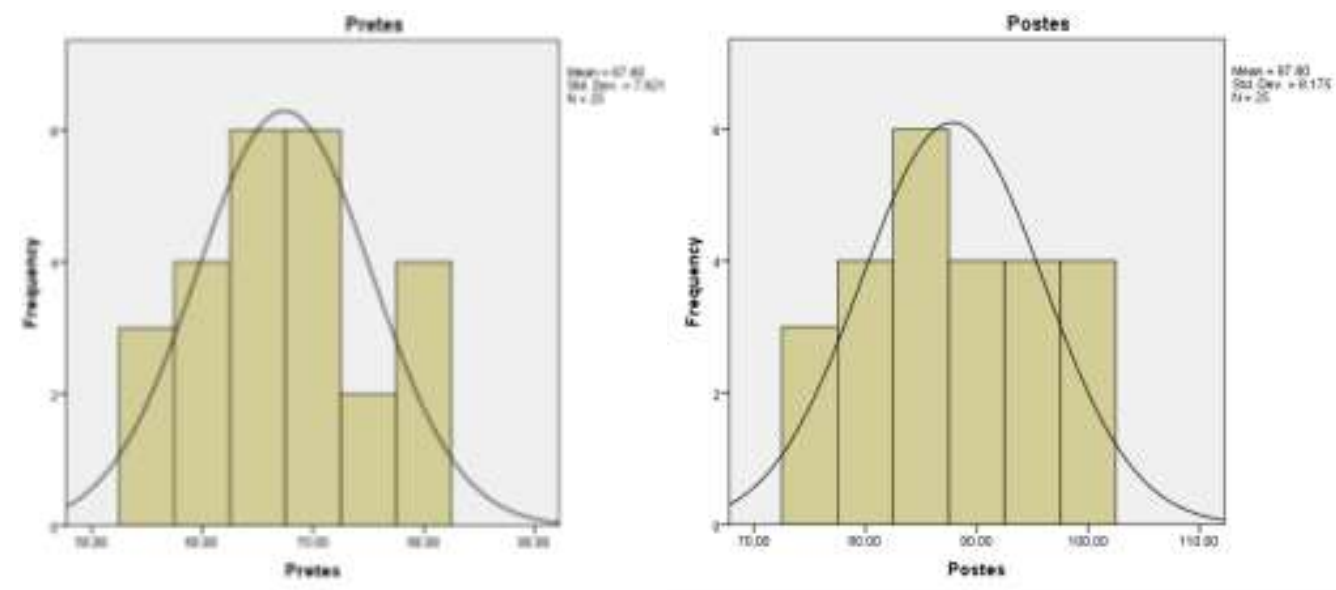

Figure 2. Histogram of Learning Outcomes of Solar System Material (Before and After)

Description of learning outcomes of the solar system before and after the use of poem and song-based proshow media shows in Table 1.

\begin{tabular}{|c|c|c|c|}
\hline \multicolumn{4}{|c|}{ Statistics Description } \\
\hline & & Pretest & Posttest \\
\hline $\mathrm{N}$ & Valid & 25 & 25 \\
\hline & Missing & 0 & 0 \\
\hline \multicolumn{2}{|c|}{ Mean } & 67.4000 & 87.8000 \\
\hline \multicolumn{2}{|c|}{ Median } & 65.0000 & 85.0000 \\
\hline \multicolumn{2}{|c|}{ Mode } & $65.00^{\mathrm{a}}$ & 85.00 \\
\hline \multicolumn{2}{|c|}{ Std. Deviation } & 7.92149 & 8.17517 \\
\hline \multicolumn{2}{|c|}{ Minimum } & 55.00 & 75.00 \\
\hline \multicolumn{2}{|c|}{ Maximum } & 80.00 & 100.00 \\
\hline \multicolumn{2}{|c|}{ Sum } & 1685.00 & 2195.00 \\
\hline
\end{tabular}

a. Multiple modes exist. The smallest value is shown

If learning outcomes are presented in the form of a histogram then as in Figure 2. Here are the results of learning solar system material before and after the use of poem and song-based proshow media. Data normality test is done through the Shapiro Wilk test with learning outcomes before the use of media proshow $p=0.73$ and after the use of media proshow $p=0.68$. Based on these results, the learning outcomes data of the solar system before and after the use of poem and song-based proshow media is normally distributed. A paired sample t-test was performed to find out its effectiveness with the results in Table 2.

Table 2. The result of Paired sample t-test

\begin{tabular}{cccc}
\hline & $\mathrm{T}$ & $\mathrm{df}$ & Sig. (2-tailed) \\
\hline Pair 1 pretest-posttest & -73.676 & 24 & 0.000 \\
\hline
\end{tabular}

Based on Table 2, the results obtained $t-73676$, while $p=0.00<0.05$. It means the development results of solar system material poem and song-based media proshow are effective in increasing student learning outcomes in class VI MI Al-Falah Soropadan.

The results of the development of the use of solar system material poem and song-based proshow media have gone through individual trials with the conclusion that the media is very feasible to use. Group trial activities also showed very decent results. Limited test on class VI MI Al-Falah Soropadan students as the final step shows that the development of poem and song-based proshow media on solar material is also very feasible. The learning outcomes of the solar system in the form of pretest and posttest data were then analyzed using SPSS 26 . The results of the statistics description analysis showed an increase in learning outcomes between pretest activities (mean: 67.4) and posttest (mean: 87.8). The research findings show that poetry-based media has an attraction for students. Lyrics of the poem are presented using words and sentences that adjust to the students' age are easier to follow and pronounce. Ease of singing with the students' interest increased makes them guided and are easier in learning. The next stage is the normality test which shows the results that the pretest and posttest data 
values are normally distributed and the last is the effectiveness test which shows that the results of $t$ count are 17,711 , while $p=0.00<0.05$.

The results of this study indicate that the development of poem and song-based proshow media on the solar system material is effective in the learning achievement of students of class VI MI Al-Falah Soropadan, Pringsurat District. It was confirmed by research Saputro (2019), which states that learning with the development of integrated scientific interpretation is effective learning. It has relevance to this study which means that the integration of poem in songs can make learning effective for students. The age of the research target who are fond of song has been optimized through learning in this study. The integration of poetry that is carried out provides a stimulus for students to learn so the objectives of learning the solar system are accomplished.

Another similar study conducted by Murdaning and Hariani (2018) states that the use of children's poem and song media can improve poem writing skills. Fatahillah et al. (2018) revealed that the media proshow displays material through audio-visual that can help students' understanding and interest so that learning outcomes increase. Students' understanding of content as a result of enjoyable learning. It means that there is an interest in learning through teacher innovation in packaging learning material in the form of songs that have an impact on the students' content understanding.

\section{CONCLUSION}

Forms of development of poem and song-based proshow media in the form of video albums contain poems about solar system material that is packaged in a variety of song variations and attractive image displays. The effectiveness of proshow learning media based on poem and songs is obtained based on the results of the t-test $=$ $17,711, p=0.00<0.05$. It shows that the development of poem and song-based proshow media on the solar system material is effective in the learning achievement of students of class VI MI Al-Falah Soropadan Pringsurat District.

\section{REFERENCES}

Akhondi, A. (2011). The effective multimedia instruction in remedy spelling disability students specific learning in Iran at year 2009. Procedia-Social and Behavioral Sciences, 15, 1951-1954.

Baharuddin, B., \& Wahyuni, E. N. (2010). Teori Belajar dan Pembelajaran. Jogjakarta: AR- Ruzz Media.

Çığrık, E., \& Ergül, R. (2010). The investion effect of using WebQuest on logical thinking ability in science education. Procedia-Social and Behavioral Sciences, 2(2), 4918-4922.

Džanić, N. D., \& Pejić, A. (2016). The Effect of Using Songs On Young Learners and Their Motivation for Learning English. NETSOL, 1(2), 1-16.

Fatahillah, F., Sudrajat, M., \& Rohmawati, A. (2018). Growing Developing Civics Literacy Through Saintific Learning Approach Model Using Learning Media Computer Proshow Gold Application, Dwija Cendekia: Jurnal Riset Pedagogik. 2(2), 32-45.

Gambarte, M. G., Mendía, R. S., García, V. I., \& García, J. G. (2014). Assessing Segurikaschool: an injury prevention multimedia tool for schools. Procedia-social and behavioral sciences, 132, 654-66o.

Ganeta, G., Syambasril, \& Syahran, A. (2014). Penggunaan Proshow Producer Untuk Meningkatkan Keterampilan Menulis Paragraf Persuasi Pada Siswa Sma Muhammadyah 1 Pontianak Program Studi Pendidikan Bahasa dan Sastra Indonesia FKIP. Pontianak: Universitas Tanjungpura Pontianak

Gorys, K. (2004). Diksi dan Gaya Bahasa. Jakarta: Gramedia Pustaka Utama.

Haghverdi, H. R. (2015). The effect of song and movie on high school students language achievement in Dehdasht. Procedia-Social and Behavioral Sciences, 192, 313-320.

Hartiningsih, S. (2015). Revitalisasi Lagu Dolanan Anak Dalam Pembentukan Karakter Anak Usia Dini, Atavisme, 18(2), 247-259.

Huda, M. (2019). Model-model Pengajaran dan Pembelajaran. Yogyakarta: Pustaka Pelajar.

Ikhsan, M. K. (2017). Boosting Students Pronunciation Through Song Dictation. Jurnal Skripsi, 2(3), 1-6. 
Imran, S. (2014). Keuntungan Media Pembelajaran Film dan Video. https://ilmu-pendidikan.net/pembelajaran /media-pembelajaran/keuntungan-media-pembelajaran-film-dan-video.

Kasihani. (2010). English for young Learners and Make me Happy. Jakarta : Bumi Aksara.

Kırıkkaya, E. B., Işseri, Ş., \& Vurkaya, G. (2009). High school students' thoughts about science on television programmes. Procedia-Social and Behavioral Sciences, 1(1), 921-926.

Koch, T., Peter, C., \& Müller, P. (2019) Experimentelle Designs und Manipulation. In: Das Experiment in der Kommunikations- und Medienwissenschaft. Studienbücher zur Kommunikations- und Medienwissenschaft. Springer VS, Wiesbaden.

Lee, T. T., \& Osman, K. (2012). Interactive multimedia module in the learning of electrochemistry: effects on students' understanding and motivation. Procedia-Social and Behavioral Sciences, 46, 1323-1327.

Liu, E. Z. F., \& Chen, P. K. (2013). The effect of game-based learning on students' learning performance in science learning-A case of "conveyance go". Procedia-Social and Behavioral Sciences, 103, 1044-1051.

Masri, M., \& Lasmi, E. (2018). Perancangan Media Pembelajaran Tata Surya Menggunakan Teknologi Augmented Reality Dengan Metode Markerless. Journal of Electrical Technology, 3(3), 40-44.

Mizener, C. P. (2008). Our singing children: Developing singing accuracy. General Music Today, 21(3), 18-24.

Murdaning, P., \& Hariani, S. (2018). Meningkatkan Keterampilan Menulis Puisi melalui Media Teks Lagu AnakAnak Siswa Kelas IV SDN Sumue Welut $1 / 438$ Surabaya. Jurnal Pendidikan Guru Sekolah Dasar, 6(3), 312321.

Patrini, I., Ruperti, M., Moccia, S., Mattos, L. S., Frontoni, E., \& De Momi, E. (2020). Transfer learning for informative-frame selection in laryngoscopic videos through learned features. Medical \& Biological Engineering \& Computing, 58, 1-14.

Portanata, L., Lisa, Y., \& Awang, I. S. (2017). Analisis pemanfaatan media pembelajaran IPA SD. Jurnal Pendidikan Dasar PerKhasa, 3(1), 337-348.

Purnomo, W., \& Subagyo, F. (2015). Terampil Bermusik, Jakarta: PT Wangsa Jastra Lestari.

Saputro, B., Mas'ud, M., Saputra, H., \& Kuswaya, A. (2019, June). Learning Effectiveness of Department-based Integrated Science Interpretation. In Journal of Physics: Conference Series (Vol. 1233, No. 1, p. 012082). IOP Publishing.

Sardiman. (2007). Interaksi dan Motivasi belajar Mengajar. Jakarta: Rajagrafindo Persada.

Sari, N. (2017). Efektivitas Penggunaan Metode Bernyanyi dengan Media Berbasis Visual terhadap Hasil Belajar Siswa Mata Pelajaran Pendidikan Kewarganegaraan Materi ASEAN Kelas VI MI Miftahul Akhlaqiyah. Laporan Penelitian. Semarang: UIN Walisongo.

Setiyadi, D. (2016). Media Pembelajaran Untuk Anak Sekolah Dasar Tentang Pengenalan Tata Surya Menggunakan Metode ComputerAssisted Instruction (CAI). Jurnal Information Management For Educators and Professionals, 1(1), 42-53.

Sudjana. (2009). Dasar-Dasar Belajar Mengajar, Bandung: Sinar Baru Algensindo.

Suprijono, A. (2015). Cooperative Learning. Yogyakarta: Pustaka Pelajar.

Susilawati. (2014). Penerapan Metode Menyanyi dalam meningkatkan kecerdasan berbahasa pada Pendidikan Anak Usia Dini. Jurnal Empowerment, 4(2), 1-11.

Tantriyadi, Y. (2013). Pembuatan ensiklopedia interaktif tata surya untuk anak SMP. Calyptra Jurnal, 2(1), 1-7.

Walker, T. D (2017). Teach like Finland, Jakarta: PT Gramedia. 